Kalamatika: Jurnal Pendidikan Matematika

\title{
IMPROVING STUDENTS' COMPETENCY ON FINANCIAL MATHEMATICS LEARNING BY APPLYING POLYAS' MODEL HEURISTIC STRATEGY
}

\author{
Justin Eduardo Simarmata ${ }^{1}$, Lailin Hijriani ${ }^{2}$ \\ ${ }^{1}$ Universitas Timor, Jalan Eltari Km. 09, Kefamenanu, Indonesia. \\ justinesimarmata@unimor.ac.id \\ ${ }^{2}$ Universitas Timor, Jalan Eltari Km. 09, Kefamenanu, Indonesia. \\ elinhijriani@unimor.ac.id
}

\section{ABSTRACT}

The research aims to depict students' ability in solving mathematical problems based on Polya's heuristic. Descriptive qualitative was used as a method in this research. Data were collected by observation, test, and interview. Based on the result of analysis obtained that the students with low level prior knowledge think heuristically in solving the problem solving test. For the students with medium level prior knowledge, the students think algorithmically and couldn't solve the problem solving test imperfectly. Furthermore, the students with high level prior knowledge think algorithmically in solving the problem solving mathematics test and the other words, the students could solve the problem solving test well and fluently.

\begin{tabular}{|c|c|}
\hline \multicolumn{2}{|c|}{ ARTICLE INFORMATION } \\
\hline Keywords & Article History \\
\hline Heuristics & Submitted July 18, 2020 \\
\hline Polya Theory & Revised Nov 12, 2020 \\
\hline Prior Knowledge & Accepted Nov 22, 2020 \\
\hline \multicolumn{2}{|l|}{ Corresponding Author } \\
\hline \multirow{4}{*}{\multicolumn{2}{|c|}{$\begin{array}{l}\text { Justin Eduardo Simarmata } \\
\text { Universitas Timor } \\
\text { Jalan Etari Km.09 Kefamenanu TTU-NTT, Indonesia } \\
\text { Email: justinesimarmata@ unimor.ac.id }\end{array}$}} \\
\hline & \\
\hline & \\
\hline & \\
\hline \multicolumn{2}{|l|}{ How to Cite } \\
\hline $\begin{array}{l}\text { Simarmata, J.E. \& Hijriani, L. (2020). Improving Stude } \\
\text { Applying Polyas' Model Heuristic Strategy. Kalamatikc }\end{array}$ & $\begin{array}{l}\text { s' Competency on Financial Mathematics Learning by } \\
\text { Jurnal Pendidikan Matematika, 5(2), 143-154. }\end{array}$ \\
\hline
\end{tabular}

https://doi.org/10.22236/KALAMATIKA.vol5no2.2020pp143-154 


\section{INTRODUCTION}

Every student has different ability to solve the problems. The ability to solve the problem is needed in their life. The students must have ability to solve the problem which related to the subjects in campus. Mathematics is prior knowledge that learn about logical form, arrangement, scale, and the other related concepts with big amount and divided into three areas, they are: algebra, analysis, and geometry (Sariningsih \& Purwasih, 2017). Therefore, hopefully the students must have cognitive ability to solve the problems well to train their cognitive skills.

NCTM (2000) states that one of the goals of mathematics learning is to develop mathematical problem solving ability. Mathematics learning is a learning that gives knowledge to the students in order to obtain the knowledge systematically or an ability to solve the problem mathematically (Wulandari et al., 2016). It is very important for the students to have ability to solve the problem because problem solving is general purpose in mathematics learning, problem solving included method, procedure, and strategy (Resilona et al., 2018). And according to Hidayat \& Sariningsih (2018) the ability to solve the problem is the main learning which is considered as prior ability in learning process. For improving the ability to solve the problem, it is important to explore the ability to comprehend the problem, make mathematics model, solve the problem, and interpretate the solution well.

Husna et al., (2013) argues that problem solving has three interpretations, namely: problem solving (1) as a main goal (2) as a process, and (3) as a basic skill. These three things have an implication in learning mathematics. Firstly, if problem solving is an objective then it is independent of problems or specific procedure, also apart from mathematical material, the most important thing is how to solve the problem until it works. In this case problem solving as the main reason for learning mathematics. Secondly, if problem solving is seen as a process, the emphasis is not solely on result, but how method, procedure, strategy and step are developed through reasoning and communication to solve problem. Thirdly, problem solving as a prior skill or life skill, because every human being must be able to solve his own problem. So problem solving is a prior skill that every student must have. The effort to practice the students' ability in mathematical problem solving is to solve problem according to the theory of Polya (Ninik et al., 2014). The steps of problem solving according to Polya theory are understanding the problem/ reading the problem, devising a plan/ choosing a strategy, carrying 
out a plan/ solving a problem and check back (Baiduri, 2015).

The research about the application of Polya's steps was carried out by (Sariati, 2013) to improve students' achievement and motivation, (Apryanti et al., 2015; Astriningsih et al., 2015) to solve the problem with mathematics story questions, (Nitya \& Partadjaja, 2013) to improve students' learning activity and outcome, (Masrurotullaily et al., 2013) to analyze the financial mathematics problem solving, (Jalal, 2013) to review the students' reasoning ability, mathematical critical thinking and creative thinking (Widyastuti, 2015) to solve the problem based on adversity quotient type climber.

In relation to the learning process, prior knowledge is an important thing that needs to be considered, to make the students learn more easily and improve the learning outcome (Salim et al., 2019). Prior knowledge as an attitude combination, experiences and students' possessed knowledge (Dirks et al., 2014). Students' prior knowledge is a number of information held by students relating to the material will be studied by students, which can help in understanding the material further (Jannah et al., 2015).

Some research that use prior knowledge as the beginning of research are (Trisna et al., 2014) to find out the influence of Write Pair Share (WPS) model to improve physics learning competency, (Jannah et al., 2015) to determine the effect of cooperative learning model with the problem posing approach, (Dharma et al., 2013) to determine the effect of the 5E- learning cycle model based on problem solving on the mathematical problem solving ability.

In problem solving, one of the models can be used is model of Polya. The steps of problem solving according to the model of Polya based on (Hobri, 2009), namely: understanding the problem, making a settlement plan, carrying out the plan, looking back. At the step of making a settlement plan, there are various kinds of strategies that are used by students to solve problem such as those who make the table first, some are looking for formulas directly, and there are those who use reasoning. When apply the various strategies, for mathematics education program students it is necessary to have an analysis of problem solving ability when solving problems related to the application of financial mathematics.

Financial mathematics is one of the subjects which available in study program of Mathematics Education. In learning process, the students will face kinds of mathematics counting. For example, in deciding the scale of interest or the scale of loan. However, it is not only about counting ability, but the students need problem solving ability when the face the 
other problems in financial scope in order to solve the problems well. Therefore, problem solving ability in scope of financial mathematics must be trained and mastered, especially for the students of mathematics education study program who has taken this subject.

Based on the explanation above, the purpose of the research is to describe and analyze the problem solving ability by applying Polya's model heuristic strategy to improve the financial mathematics learning competency based on students' prior knowledge of Universitas Timor.

\section{METHOD}

This research is a descriptive qualitative research aimed to describe the ability of students to solve mathematical problems according to the polya theory based on prior knowledge. This research was conducted at the mathematics education program students Universitas Timor, odd semester (2019-2020). Participants in this research amounted to 2 classes. The instruments in this research are the researchers themselves and tests.

The method used in this research is the observation method, tests, and interview. There were two tests, namely: pre-test and post-test. Pre-test and post-test contained of the same questions but the problem solving sheet on pre-test was not given instructions on how students to solve problems while in post-test, were given instructions about the steps which must be conducted by the students to solve the problem. These steps were problem solving steps based on Polya's model. Based on the post-test result, the students were chosen to be interviewed in this research. Interview was conducted with six students. And the data was analyzed by using simple statistics based on the mean.

Data was collected through learning outcomes tests. The test instrument was used to determine the completeness of student learning outcomes. Scores obtained by students which were converted become grades ranging from 0-100 to determine the completeness of students' learning outcomes. This research is said to be successful in achieving the target if $\geq 70 \%$ of students completed individually or scored above 60.

The validity of an instrument showed the accuracy level of an instrument to measure what must be measured. Therefore, the validity of an instrument related to the accuracy level of a measuring instrument to measure what would be measured. In this research, validity testing was conducted on 75 respondents. Because there was a sample $(\mathrm{N})$ of 75 , the r-table value was 0.224 . This value was compared with $r$-count, if r-table was greater than r-count 
then the conclusion of this statement was invalid, but if the r-table value was smaller than $\mathrm{r}$ count in SPSS then the conclusion was valid. Because the calculated value is 0.726 , this statement was automatically valid $(0.726>0.224)$. The reliability test was a set of measuring devices that had consistency if the measurements made with the measuring instrument were repeated. The test was declared reliable or consistent if Alpha Cronbach $>0.600$ but if Alpha Cronbach $<0.600$ test was declared unreliable or inconsistent. Based on calculations with SPSS, Alpha Cronbach's value $=0.816$ was obtained, Alpha Cronbach's value was greater than 0.600 , which meant the test was reliable and could be used in this research.

\section{RESULT AND DISCUSSION}

Based on the research, we could see the result of the students' scores by applying olyas' model heuristic strategy. From the result, it showed that there was improvement of the students' scores.

Based on the pre-test and post-test, which have been conducted, students of class A who completed the learning outcomes according to the expected indicators were 13 students with a percentage of $46 \%$ for the final ability of students who completed as many as 21 students with a percentage of $75 \%$. For class B, the prior ability acquisition was 29 students with a percentage of $61 \%$ and the final ability acquisition was obtained as many as 36 students with a percentage of $76 \%$. For completeness of recapitulation individually can be seen on the table 1 .

Table 1. Completeness Percentage Recapitulation Individually

\begin{tabular}{lcc}
\hline No & Class A & Class B \\
\hline 1 & 21 & 36 \\
Percentage (\%) & $75 \%$ & $76 \%$ \\
\hline
\end{tabular}

Based on table 1, the completeness of students' learning outcomes individually, the results of pre-test and post-test were obtained 21 students of class A who could improve ability based on indicator with percentage $75 \%$. For class B, there was 36 students with percentage $76 \%$.

Table 2. Grouping of Student's Mathematical Prior Knowledge Level

\begin{tabular}{llcc}
\hline No & Knowledge Level & \multicolumn{2}{c}{ Class } \\
& & A & B \\
\hline 1 & High level prior knowledge & 5 & 10 \\
2 & Medium level prior knowledge & 8 & 19 \\
3 & Low level prior knowledge & 15 & 18 \\
Total & & 28 & 7 \\
\hline
\end{tabular}


Based on table 2, there were many students who had low ability in prior knowledge or under average and there were little students who had high ability.

Table 3. Grouping of Students' Mathematical Post-test Score

\begin{tabular}{llcc}
\hline No & Knowledge Level & \multicolumn{2}{c}{ Class } \\
& & A & B \\
\hline 1 & High level prior knowledge & 15 & 21 \\
2 & Medium level prior knowledge & 6 & 15 \\
3 & Low level prior knowledge & 7 & 11 \\
Total & & 28 & 47 \\
\hline
\end{tabular}

After conducting financial mathematics learning in class $A$, we could see the improvement from low, medium, and high level of prior knowledge as seen in table 3.

The following is a student's ability to solve problems according to high, middle and low prior knowledge.

\section{Problem solving analysis for students with high mathematical prior knowledge}

Based on the data was obtained from the written test result and interview it was found that in both questions used, students with a high mathematical knowledge level can understand the problem that exist in the test, able to write anything that is known and asked about the test, and able to answer all the test correctly. But the number of students who have a high level of mathematical ability is not too much at the time of the initial test, but at the time of the final test students who have a high ability level both of class A and class B are more than the initial test. It is suspected that was indicated from the limited of students' ability to transfer sentences in the form of story questions to the mathematics model and their confidence has not been built in working the test (Khaerani \& Syamsuriywati, 2018). Based on the explanation, it can be concluded that not all students are able to understand the problems that exist in the test. Students with a high level of mathematical knowledge can also plan well, be able to use all the elements that are known to solve the problems, be able to carry out solutions according to the plans made. They are also able to write down how to look back the answers that have been obtained. They solve mathematical problem solving test algorithmically that is thinking according to the steps of Polya's theory and able to convey ideas and communicate well in accordance with what have done.

\section{Problem solving analysis for students with middle mathematical prior knowledge}

Students with a middle level of mathematical knowledge are able to understand the problems that exist in the test, can do the planning well, are able to use all the elements that are known to solve problems, able to carry out solutions according to the plan made. However, 
they have not been able to write down how to look back the answers that have been obtained on the test given. They can solve mathematical problem solving algorithmically but are not perfect based on the steps of Polya's theory. They are able to convey idea and communicate well in accordance with what have done. That statement is relevant with the research which has been done by (Mandasari, 2018), there are students who have ability to solve the problem solving questions well but incomplete with the steps of Polya, in other words the students are able to make the problem conclusion of the questions well. The students have been able to answer the questions well but the way they choose to obtain the answer incorrect. Problem solving analysis for students with low mathematical prior knowledge

Students with low mathematical knowledge level, they lack to understand the problems in the test given. Although they are able to write down what it known and asked on the test, they are not able to explain what has been done on the work sheet. They are only able to answer 1 problem correctly but cannot explain it. They also cannot plan well, unable to use all the elements known to solve problems. In addition, they are less able to carry out problem solving. They are not able to explain the calculation process that has been made and have not been able to mention and write down how to look back the answers that have been obtained in the test given. They solved the mathematical problem solving test heuristically by working on trial and error without paying attention to the steps of Polya's theory. And students are less able to convey idea and less able to communicate properly in accordance with what have done, and unable to explain the work results that obtained (Mandasari, 2018).

Based on the results of a simple statistical analysis using the mean count, it can be concluded that there is a significant difference between mathematics learning outcomes before and after the learning method which is given by using the problem solving method according to Polya. Analysis results are supported by previous researchers namely (Jannah et al., 2015) who in their research found that the influence of prior knowledge on problem solving ability shows that students who have high prior knowledge are better than students who have low prior knowledge.

\section{CONCLUSION}

In general, the results of financial mathematics learning (post-test), students in solving mathematical problems using the theory of polya increased, when it compared with the prior ability test (pre-test). This shows that students have understood the steps of Polya correctly 
and are able to apply the steps of the Polya problem in solving the test that given.

Students with high prior knowledge level think algorithmically in solving mathematical problem solving problems that are able to understand problems correctly and smoothly. Students with middle prior knowledge level are thinking algorithmically imperfectly in solving problem solving test. Students with low prior knowledge level think heuristically in solving mathematical problem solving test.

\section{ACKNOWLEDGMENTS}

Thank you to the Chancellor of Universitas Timor, Kefamenanu and his staff who allowed us to participate in independent research activity. The same speech is addressed to the Dean of the FIP and Chair of the Mathematics Education Study Program at the Universitas Timor. Researchers would like to thank the Chairman of the UPT LPPM Universitas Timor and his staff for providing material support with SK No.038/UN60/LPPM/2020 and also for students who have helped in the process of research data collection.

\section{REFERENCES}

Apryanti, H., Ismail, F., \& Fitrianti, Y. (2015). Penerapan Teknik Pemecahan Masalah Model Polya Terhadap Kemampuan Menyelesaikan Soal Cerita Matematika Pada Siswa Kelas VIII SMP Negeri 46 Palembang. Jurnal Pendidikan Matematika JPM RAFA, 1(2), 224243. http://jurnal.radenfatah.ac.id/index.php/jpmrafa/article/view/1232

Astriningsih, N. K., Sedanayasa, G., \& Japa, G. N. (2015). Penerapan Model Polya Berbantuan Soal Cerita Untuk Meningkatkan Hasil Belajar Matematika Siswa Kelas V Semester I. Journal PGSD Universitas Pendidikan Ganesha Jurusan PGSD, 3(1), 1-9. http://dx.doi.org/10.23887/jjpgsd.v3i1.6244

Baiduri. (2015). Pengaruh Tahapan Polya Dalam Pemecahan Masalah Terhadap Ketuntasan Belajar Geometri Siswa Sekolah Menengah Pertama Stages influence Polya In Troubleshooting Against Mastery Learning Geometry. Jurnal Pendidikan Matematika, 6(1), 41-48. http://dx.doi.org/10.36709/jpm.v6i1.2060

Dharma, N. I., Sadra, W. I., \& Sariyasa. (2013). Pengaruh Pendidikan Matematika Realistik Terhadap Pemahaman Konsep Dan Daya Matematika Ditinjau Dari Pengetahuan Awal Siswa SMP Nasional Plus. Jurnal Pendidikan Dan Pembelajaran Matematika Indonesia, 
2(2). http://119.252.161.254/e-journal/index.php/JPM/article/view/906

Dirks, A., Yudana, I., \& Dantes, G. (2014). Pengaruh Penerapan Blended Character Education Approach Untuk Meningkatkan Hasil Belajar Sejarah Ditinjau Dari Pengetahuan Awal Pada Siswa Di SMAK Thomas Aquino Tangeb, Mengwi, Badung. Jurnal Administrasi Pendidikan Indonesia, 5(1), $\quad 1-10 . \quad$ http://119.252.161.254/ejournal/index.php/jurnal_ap/article/view/1326

Hidayat, W., \& Sariningsih, R. (2018). Kemampuan Pemecahan Masalah Matematis dan Adversity Quotient Siswa SMP Melalui Pembelajaran Open Ended. Jurnal Nasional Pendidikan Matematika, 2(1), 109-118. http://dx.doi.org/10.33603/jnpm.v2i1.1027

Hobri. (2009). Pembelajaran Matematika Berorientasi Vocational Skill dengan Pendekatan Kontekstual Berbasis Masalah Kejuruan. Malang: Universitas Negeri Malang (UM Press).

Husna, Ikhsan, M., \& Fatimah, S. (2013). Peningkatan Kemampuan Pemecahan Masalah Dan Komunikasi Matematis Siswa Sekolah Menengah Pertama Melalui Model Pembelajaran Kooperatif Tipe Think-Pair-Share (Tps). Jurnal Peluang, 1(2), 81-92.

Jalal, A. (2013). Keefektifan Pembelajaran Matematika Dengan Pendekatan Pemecahan Masalah Model Polya Ditinjau Dari Kemampuan Penalaran, Berpikir Kritis, Dan Berpikir Kreatif Matematik Pada Siswa Sma Negeri 5 Kota Ternate. Delta-Pi: Jurnal Matematika dan Pendidikan Matematika, 2(1), 76-83. http://dx.doi.org/10.33387/dpi.v2i1.101

Jannah, S. N., Doyan, A., \& Harjono, A. (2015). Pengaruh Model Pembelajaran Kooperatif Dengan Pendekatan Problem Posing Ditinjau Dari Pengetahuan Awal Terhadap Kemampuan Pemecahan Masalah Fisika Siswa SMK. Jurnal Pendidikan Fisika Dan Teknologi, 1(4), 2407-6902.

Khaerani, \& Syamsuriywati. (2018). Pengaruh Intelegensi Ganda Terhadap Kemampuan Menyelesaikan Soal Cerita Pada Mata Kuliah Geometri Analitik Ruang Mahasiswa Pendidikan Matematika Universitas Muslim Maros. Pedagogy: Jurnal Pendidikan Matematika, 3(2), 42-53. https://doi.org/http://dx.doi.org/10.30605/pedagogy.v3i2.1184 
Mandasari, L. (2018). Analisis Kemampuan Pemecahan Masalah Mahasiswa Pendidikan Matematika Pada Mata Kuliah Pemodelan Matematika. Jurnal As-Salam, 2(2), 68-75. https://doi.org/10.37249/as-salam.v2i2.35

Masrurotullaily, Hobri, \& Suharto. (2013). Analisis Kemampuan Pemecahan Masalah Matematika Keuangan Berdasarkan Model Polya Siswa SMK Negeri 6 Jember. Kadikma, 4(2), 129-138. http://jurnal.unej.ac.id/index.php/kadikma/article/view/1045

NCTM. (2000). Principles and Standards for School Mathematics. Reston, Virginia : NCTM.

Ninik, Hobri, \& Suharto. (2014). Analisis Kemampuan Pemecahan Masalah Untuk Setiap Tahap Model Polya Dari Siswa SMK Ibu Pakusari Jurusan Multimedia Pada Pokok Bahasan Program Linier. Kadikma, 5(3), 61-68. https://doi.org/10.12681/er.9602

Nitya, G. E. P. D., \& Partadjaja, I. W. K. T. R. (2013). Penerapan Model Polya Untuk Meningkatkan Aaktivitas dan Hasil Belajar Matematika Dalam Menyelesaikan Soal Cerita Pada Siswa Kelas V SD No.2 Pemaron. Mimbar PGSD Undiksha, 1(1), 1-10. http://dx.doi.org/10.23887/jjpgsd.v1i1.1454

Resilona, S. F., Hidayat, W., \& Hendriana, H. (2018). Peningkatan Kemampuan Pemecahan Masalah Melalui Pembelajaran Berbasis Masalah Siswa SMP. Jurnal Pembelajaran Matematika Inovatif, 1(4), 487-492. https://doi.org/60/jpmi.v1i4.p487-492

Salim, Suryaman, \& Rusmawati, R. D. (2019). Keefektifan Tingkatan Pembelajaran Inkuiri (Levels Of Inquiry) terhadap Peningkatan Keterampilan Proses Sains Pada Siswa Dengan Pengetahuan Awal Berbeda. Edcomtech, 4(2), 96-108. https://doi.org/DOI 10.17977/um039

Sariati, K. (2013). Penggunaan Strategi Heuristik Model Polya Pada Pembelajaran Pemecahan Masalah Matematika Untuk Meningkatkan Prestasi Belajar Siswa Kelas VIII B SMP Negeri 40 Purworejo Tahun Pelajaran 2011/2012. Ekuivalen-Pendidikan Matematika, 1(1), 28-34. https://doi.org/10.37729/ekuivalen.v1i1.290

Sariningsih, R., \& Purwasih, R. (2017). Pembelajaran Problem Based Learning Untuk 
Meningkatkan Kemampuan Pemecahan Masalah Matematis dan Self Efficacy Mahasiswa Calon Guru. JNPM (Jurnal Nasional Pendidikan Matematika), 1(1), 163-177. http://ppjp.unlam.ac.id/journal/index.php/JDK/article/view/3189/2737

Trisna, S., \& Pratiwi, P. (2014). PENGARUH MODEL PEMBELAJARAN WRITE PAIR SHARE (WPS) DALAM MENINGKATKAN KOMPETENSI PEMBELAJARAN FISIKA DITINJAU DARI PENGETAHUAN AWAL MAHASISWA STKIP PGRI SUMATERA BARAT. JRFES (Jurnal Riset Fisika Edukasi dan Sains), 1(1), 19-27. https://doi.org/10.22202/jrfes.2014.v1i1.1182

Widyastuti, R. (2015). Proses Berpikir Siswa dalam Menyelesaikan Masalah Matematika berdasarkan Teori Polya ditinjau dari Adversity Quotient Tipe Climber. In Jurnal Pendidikan Matematika (Vol. 6, Issue 2). https://doi.org/10.24042/ajpm.v6i2.48

Wulandari, P., Mujib, M., \& Putra, F. G. (2016). Pengaruh Model Pembelajaran Investigasi Kelompok berbantuan Perangkat Lunak Maple terhadap Kemampuan Pemecahan Masalah Matematis. Al-Jabar: Jurnal Pendidikan Matematika,7(1), 101-106. http://www.ejournal.radenintan.ac.id/index.php/al-jabar/article/view/134 
154 KALAMATIKA, Volume 5, No. 2, November 2020, pages 143-154 